\title{
Mood Structure Analysis and Thematisation Patterns in Niyi Osundare's "My Lord, Tell Me Where to Keep Your Bribe"
}

\author{
Toyese Najeem Dahunsi ${ }^{1} \&$ Sola Timothy Babatunde ${ }^{2}$ \\ ${ }^{1}$ Department of General Studies, Federal Polytechnic, Ile-Oluji, Ondo State, Nigeria \\ ${ }^{2}$ Department of English, Faculty of Arts, University of Ilorin, Nigeria \\ Correspondence: Toyese Najeem Dahunsi, Department of General Studies, Federal Polytechnic, Ile-Oluji, Ondo \\ State, Nigeria. Tel: 234-806-720-0262. E-mail: deoladahunsi@gmail.com
}

\author{
Received: February 6, 2017 Accepted: February 18, 2017 Online Published: March 1, 2017 \\ doi:10.5539/ijel.v7n3p129 URL: http://doi.org/10.5539/ijel.v7n3p129
}

\begin{abstract}
One of the theories that seek to unravel how the human language functions is the Systemic Functional Grammar (SFG). SFG achieves its uniqueness by seeking to develop a theory about language as a social process and an analytical methodology for detailed and systematic description of language patterns (Eggins, 2004). Given its suitability for the analysis of any text, SFG was used in this study for the analysis of the poem "My Lord, Tell Me Where to Keep Your Bribe". Though SFG shows how three different strands of meanings (ideational, interpersonal and textual) are expressed in the structures of clauses, the focus of analysis was on the grammar of textual and interpersonal meanings, hence the thematic and Mood structure analyses of the poem. The thematisation patterns identified in the poem included the use of textual themes (for inter-clause cohesive purposes), interpersonal themes (for the assignment of Mood labels to clauses) and topical themes, which altogether enabled the poet bring into thematic prominence the major issues of worry to an average Nigerian who had always thought judges and the courts of law should be immune from corruption. The Mood structure analysis showed the poet's conscious choices of the indicative Mood, with alternating options of interrogative and declarative clause types. Overall, the SFG-based analysis showed how the poet made conscious paradigmatic choices and arranged them into linear (syntagmatic) structures to make the different meanings conveyed in the poem.
\end{abstract}

Keywords: systemic functional grammar, textual meanings, thematisation patterns, interpersonal meanings, mood structure

\section{Introduction}

The analysis of texts (written and spoken) using acceptable analytical theories and frameworks is one of the major pre-occupations of linguists. The word "text" has been defined in linguistics in various ways. Halliday \& Hasan (1976, p. 1) describe a text as "any passage, spoken or written, of whatever length, that does form a unified whole". Beaugrande \& Dressler (1981) define text as a communicative occurrence which meets seven standards of textuality. They enumerated the standards of textuality to include cohesion, coherence, intentionality, acceptability, informativity, situationality, and intertextuality. Halliday \& Matthiessen (2014) in their description of a text maintain that "when people speak or write, they produce text; and text is what listeners and readers engage with and interpret". They proceed to define text succinctly as "any instance of language, in any medium, that makes sense to someone who knows the language" (Halliday \& Matthiessen, 2014, p. 3). Textual analysis has often been carried out with different motives and from different academic disciplines including law, linguistics, sociology and psychology. In linguistics, there are different perspectives on the analysis of texts, one focusing on text as an object in its own right, and two, focusing on text as an instrument for finding out about something else (Halliday \& Matthiessen, 2014).

The analysis of written and spoken texts has often come from different linguistic perspectives. There are studies on the analysis of patterns of language in use and the ways in which these relate to social and cultural patterns (Hutchby \& Wooffitt, 2008) with the adoption of the sociology based Ethnography of Communication (Hymes, 1972; Hymes, 1974; Gumperz \& Hymes, 1982). This analytical framework is used to discover the varieties of forms and functions available for communication, and the ways such forms and functions are part of different ways of life (Schiffrin, 2007). There are studies that have adopted Conversational Analysis (CA) for textual 
analysis, particularly for spoken texts, with the aim of looking at the actions that form the interactions of people through language (Sacks, 1992) and, according to Schiffrin (2007, p. 232), "how language both creates and is created by social context". Other linguistic dimensions of textual analysis include phonological, grammatical, pragmatic, and, of recent, forensic analysis, all of which have produced one form of contribution or another to knowledge. In short, the objectives of undertaking textual analyses can be as varied and numerous as the number of scholars conducting such analyses.

One of the theories and analytical frameworks frequently adopted for textual analysis is Systemic Functional Grammar (SFG), a postulation of Michael Alexander Kirkwood Halliday, a British-born Australian linguist. Though the linguistic model has its foundation in Halliday's publication of 1961 titled "Categories of the Theory of Grammar", it became prominent and more novel after his publication of An Introduction to Functional Grammar in 1985. Halliday (1985, p. xiv) describes the theory as one, "by which a language, or any other semiotic system, is interpreted as networks of interlocking options... whatever is chosen in one system becomes the way into a set of choices in another". SFG deals largely with the structural organization of English clauses, yet Halliday's interest is substantially on the meanings of language in use in the "textual processes of social life", or "the sociosemantics of texts", (Eggins, 2004, p. 2). Halliday (1994) further explains that:

... the aim has been to construct a grammar for purposes of text analysis: one that would make it possible to say sensible and useful things about any text, spoken or written, in modern English, (p. xv).

As a further description of the framework and contrasting it with other theories of language, Halliday \& Matthiessen (2014) maintain, that:

Systemic theory gets its name from the fact that the grammar of a language is represented in the form of system networks, not as an inventory of structures. Of course, structure is an essential part of the description, but it is interpreted as the outward form taken by systemic choices, not as the defining characteristic of language (p. 23).

The general assumptions on which SFG operates as Eggins (2004, p. 3) notes are that language is "functional, semantic, contextual and semiotic". Following from this, SFG and systemicists focus on how people use language (that is, how they negotiate texts to make meanings) in different contexts, and how language is structured to be able to convey interactants' desired meanings. Thus, for Halliday and SFG, as Fontaine (2013, p. 5) explains, "the ways in which we can create meanings through language are organized through patterns of use", with language seen as a "system of options". Central to SFG is the focus on the clause as the basic unit of analysis, with the postulation that the clause is multi-functional, having three types of meanings expressed in it. These three types of meaning are ideational (that is, construing experience function) elsewhere referred to as experiential (Thompson, 2004), interpersonal (enacting social relationships function) and textual ("creating discourse" function), technically described by Halliday (1985), Halliday \& Matthiessen (2004) and Halliday \& Matthiessen (2014), Butt et al. (2003) as the metafunctions of language. As Hasan (2009) explains, the metafunctions are not hierarchical. They are of equal status and are all woven into language use.

Generally, SFG views language as a resource which humans use to express meanings in contexts. The resources inherent in language which are used to convey meanings are the lexical (words) and grammatical (combinatorial possibilities of words to form larger units) resources. Halliday \& Matthiessen (2014) refer to lexis and grammar as "two poles of a single (lexicogrammar) cline" (p. 64), with lexis operating on the paradigmatic axis and grammar operating on the syntagmatic axis. These two axes define the different relations between linguistic signs: syntagmatic relations, being relations along the axis of chain, and one by which "signs can go together in sequences or structures", and paradigmatic relations, being relations along the axis of choice, are the relations by which signs stand in opposition to other signs that might have occurred in its place (Eggins, 2004, p. 190).

As contexts of language use vary from situation to situation, so do the choices of language resources vary. For example, a courtroom communication between a lawyer and an accused person will involve a set of questions and answers, whereas a story-telling session between an adult and some children will involve narrations and less of questioning. These are two different communicative contexts with two different communicative goals. The communicative goal in courtroom communication is fact-finding and propositional confirmation-denial, whereas it is informative education in a story-telling communicative context. The same language resources cannot be used to achieve these communicative goals, hence the evolution of different registers for each of the communicative situations. SFG therefore predominantly accounts for how speakers and writers use lexical and grammatical resources to achieve meanings. Thompson (2004) aptly submits that

Functional Grammar sets out to investigate what the range of relevant choices are, both in the kinds of meanings that we might want to express (or functions that we might want to perform) and in the kinds of wordings that we 
can use to express these meanings (p. 8).

In much different veins at recent annals of literature, some other considerable studies have also been conducted in SFL to lexico-grammatically and semantically investigate various texts and discourses to discern multiple strategies exploited by orators and authors in political, scientific, religious etc. texts to make the texts persuasive, significant, appealing and obscure as well (Cap \& Okulska, 2013; Kazemian et al., 2013; Kazemian \& Hashemi, 2014; Noor et al., 2015; Zhou \& Kazemian, 2015; Nur, 2015). Prior studies have tended to concentrate on some other genres and discourses. This study is unique in the sense that it attempts to bridge the gap among previous studies by focusing on the mood structure analysis and thematisation patterns in Niyi Osundare's poem: “my lord, tell me where to keep your bribe".

\subsection{An Overview of Interpersonal and Logical Meanings of Clauses: Mood System and Thematic Structure}

The idea of interpersonal meanings of the clause is derived from SFG's view that when humans speak, they use language to enact some social relationship among one another. Eggins (2004) posits that dialogue "is the means language gives us for expressing interpersonal meanings about roles and attitudes. Being able to take part in dialogue, then, means being able to negotiate the exchange of interpersonal meanings" (p. 144). The focus of interpersonal meaning analysis is therefore to unravel how lexico-grammatical resources are structured into clauses to enable people establish relationship in terms of speech roles in the communicative exchange. A dialogue is developed by each interactant taking some speech role (such as demanding) and assigning a complementary speech role (such as giving) to the other interactant. Giving and demanding are acts of communicative exchange, which involve some form of commodity. The choice of the commodity is between exchanging information (where the clause takes on the form of proposition) and exchanging goods-and-services (where the clause takes on the form of proposal, with examples below and illustration in Figure 1).
1) Who won the last elections in America?
(Information exchange, proposition)
2) When did Nigeria gain independence?
(Information exchange, proposition)
3) Give me my stipend for the month.
(Goods-and-services exchange, proposal)
4) Take my part and give Debby please.
(Goods-and-services exchange, proposal).

\begin{tabular}{|l||c|c|}
\hline role in exchange & (a) Goods-and-services & (b) Information \\
\hline (i) Giving & & Offer \\
\hline (ii) Demanding & I will teach you Indi & $\begin{array}{c}\text { statement } \\
\text { I know it aiready }\end{array}$ \\
\hline
\end{tabular}

Figure 1. Basic speech roles

As Halliday \& Matthiessen (2014, p. 134) theorise, though there are other resources and systems such as polarity and modality, "the principal grammatical system" for the realization of the interpersonal meanings of the clause as exchange is the Mood system. The Mood system constitutes the resources used for grammatical variations in clauses, and these variations and the combinatorial differences in the Mood structure of clauses lead to different clausal configurations and types. Halliday \& Matthiessen (2014, p. 143) explain:

(1) The presence of the Mood element, consisting of Subject plus Finite, realizes the feature "indicative".

(2) Within the indicative, what is significant is the order of Subject and Finite:

a) The order Subject before Finite realizes "declarative";

b) The order Finite before Subject realizes "yes-no interrogative";

c) In a "WH- interrogative" the order is: (i) Subject before Finite if the WH- element is the Subject; (ii) Finite before Subject otherwise.

The English clause typically contains the Mood and the Residue. The Mood as a concept in SFG is not about the 
state of mind of speakers. The Mood is a technical term in SFG that has to do with the use of lexico-grammatical resources to enact social relationship through language. The Mood here is realised by a combination (and variation) of the Subject (that is, something by which the proposition in the clause can be affirmed or denied) and the Finite (something that circumscribes and makes the proposition in the clause finite), while the Residue comprises all other constituents of the clause including the Predicator, Complement and Adjunct, as argued by Halliday \& Matthiessen (2014). Thus, the clauses I have not been taking my drugs as recommended in recent times and Out of frustration, the Vice-Chancellor resigned from office last Friday are analysed as shown in Figures 2 and 3.

a) I have not been taking my drugs as recommended in recent times.

\begin{tabular}{llllll}
\hline I & have not & been taking & my drugs & as recommended & in recent times \\
\hline $\begin{array}{l}\text { Subject } \\
\text { Mood Block }\end{array}$ & Finite (neg. polarity) & Predicator & Complement & Adjunct $^{1}$ & Adjunct $^{2}$ \\
& Residue & & & \\
\hline
\end{tabular}

Figure 2. Mood analysis of a clause with overt finite

b) Out of frustration, the Vice-Chancellor resigned from office last Friday.

\begin{tabular}{|c|c|c|c|c|}
\hline Out of frustration & the Vice-Chancellor & resigned & from office & last Friday \\
\hline Adjunct $^{1}$ & Subject & (Fused) Finite & Adjunct $^{2}$ & Adjunct $^{3}$ \\
\hline Residue & Mood Block & & Residue & \\
\hline
\end{tabular}

Figure 3. Mood analysis of a clause with fused finite

Clause example i. above has the Mood realised by the Subject $I$ and the Finite (showing negative polarity) have not while the Residue comprises the Predicator element been taking, the Complement element my drugs, the Adjunct ${ }^{1}$ and Adjunct ${ }^{2}$ elements as recommended and in recent times respectively. Clause example ii. has the Mood realised by the Subject the Vice-Chancellor and Finite (fused with the Predicator) resigned, while the residue comprises the Adjunct ${ }^{1}$ element out of frustration and both Adjunct ${ }^{2}$ and Adjunct ${ }^{3}$ elements from office and last Friday. The arrangement of the Subject and the Finite in the modal structure varies in a number of ways, and these variations determine the type of Mood inherent in a clause. Again, the arrangement of the Modal elements (Subject and the Finite) with other clausal constituents that make-up the Residue is at the syntagmatic relation of the Mood, where functional constituents are structured. A paradigmatic relation that exists among constituents of clauses involves systems. The basic system consists of an entry condition and a set of two or more signs in opposition, of which one and only one must be chosen (Eggins, 2004, p. 194). Thus, in using language, humans make conscious paradigmatic choices among mutually exclusive options and arrange them in patterned syntactic structures to achieve meanings.

Thematisation, on the other hand, is argued to be the line of meaning "that gives the clause its character as message" (Halliday \& Matthiessen, 2014, p. 88). If clauses are used to convey messages, then it is believed that such message has a pattern of organization, wherein a distinct status is assigned to one part of the clause (theme), and that part combines with all other parts of the clause (Rheme) to make the complete message that is conveyed by the clause. Halliday \& Matthiessen (2004, p. 64) describe the Theme as "the starting-point for the message: It is what the clause is going to be about". They further explain (Halliday \& Matthiessen, 2014, p. 89) that the Theme is the element that serves as "the point of departure for the message, that is, that which locates and orients the clause within its context"; and it is "what sets the scene for the clause itself and positions it in relation to the unfolding text" (p. 90). As Eggins (2004) notes, the identification of the Theme is based on information order in the clause, that is, which information unit comes first and which others follow. There are three basic types of Themes. These include topical themes, where a Transitivity function can be assigned to the elements that occupy the first position (as in Masquerades [sayer, topical] sing like idols; In April 2016 [circumstance: temporal, topical], I was one of the brightest). There are also interpersonal Themes, when the element that occupy the first position in the clause is part of the Mood block, usually the Finite (as in Can [the Finite, interpersonal] we now come together please) or serves as mood/vocative/comment/polarity adjuncts (as in quite unfortunately [comment adjunct, interpersonal], they all have to resign). The third Theme type is textual Theme, where the element coming first in the clause does not play Transitivity and interpersonal role, but serves the cohesive purpose of relating the clause to its context (as in Well [continuity adjunct, textual], we have to do it once and for all). Eggins (2004) suggests the following method in the thematic analysis of clauses (examples in iii and iv 
below):

Simply take each clause in a text and assign a label of interpersonal, textual or topical to the elements at the beginning. If the first element is a topical element, you call that THEME, and all the rest of the clause is RHEME. If other elements (interpersonal, textual) come before the topical element, you include them in the THEME, up to the end of the first topical element (Eggins, 2004, p. 308).

c) The contestants have filled in and submitted their nomination forms.

\begin{tabular}{ll}
\hline The contestants & have filled in and submitted their nomination forms \\
\hline Topical & \\
Theme & Rheme \\
\hline
\end{tabular}

d) Should I break the door before you bring the bag out?

\begin{tabular}{lll}
\hline Should & I & break the door before you bring the bag out? \\
\hline $\begin{array}{l}\text { interpersonal } \\
\text { Theme }\end{array}$ & topical & \\
& & Rheme \\
\hline
\end{tabular}

e) No, we are not going to take that shit.

\begin{tabular}{lll}
\hline No & We & are not going to take that shit \\
\hline Textual (continuative Adjunct) & topical & \\
Theme & & Rheme \\
\hline
\end{tabular}

\section{The Material Studied and Method of Analysis}

The text chosen for analysis is (the Nigerian) Niyi Osundare's "My Lord, Tell Me Where to Keep Your Bribe". Niyi Osundare is a Nigerian, poet, dramatist and literary critic. The poem is a 24-stanza satirical reaction to the shocking discovery of some Nigerian judges' involvement in corruption in October 2016. The judiciary, of which judges are principal agents, is believed to be the last hope of the common man. Judges are expected to be unbiased, fair and just in the discharge of their duties. The Nigerian public was therefore astonished about the newspaper reports of allegations of corruption and particularly with evidence-based reports of illicit keeping of huge amounts of ill-gotten money in hard and local currencies in roof-tops and other ridiculous non-banking places by the judges. Each of the cases was promptly investigated and the judges involved were being prosecuted in the courts of law. Though the shocking discovery was greeted by reactions on the print and electronic media, Niyi Osundare's satirical poem was the first literary reaction. The poem was published after few days of the press reports, and it was widely circulated on the social media.

The poet's thematic pre-occupation is the satirisation of Nigerian judges, their deep involvement in corruption and subversion of justice, the ridiculous places they keep ill-gotten wealth, and the enormous enervating effect of biased judgements and corrupt judiciary on national development. To be able to convey these broad messages, the poet has used selected lexical and grammatical resources of English in systematic and conscious ways. Broadly, the Systemic Functional Grammar was used as analytical framework for the study, but the main focus was the analysis of the interpersonal meanings and logical meanings of the clause. With this in mind, the whole text was first analysed into component clauses, and for each of the clauses, the thematic structure was analysed, followed by the Mood structure analysis following Halliday \& Matthiessen (2014), Eggins (2004) and Thompson (2007) models. Three examples of such analyses are presented below.

a) Shall I give a billion to each of your paramours the black, the light, the Fanta-yellow?

\begin{tabular}{|c|c|c|c|c|c|}
\hline \multirow{7}{*}{ Clause 8.} & \multicolumn{2}{|c|}{ Theme-Rheme structure } & \\
\hline & Shall & I & \multirow{2}{*}{\multicolumn{3}{|c|}{$\begin{array}{l}\text { give a billion to each of your paramours the black, the light, the Fanta-yellow } \\
\text { Rheme }\end{array}$}} \\
\hline & $\begin{array}{l}\text { interpersonal } \\
\text { Theme }\end{array}$ & $\begin{array}{l}\text { Topical } \\
\text { Theme }\end{array}$ & & & \\
\hline & \multicolumn{5}{|c|}{ Modal structure } \\
\hline & Shall & I & give & a billion & to each of your paramours the black, the light, the Fanta-yellow. \\
\hline & Finite & Subject & Predicator & Complement & Adjunct \\
\hline & Mood & & Residue & & \\
\hline
\end{tabular}


b) Just one judgement sold to the richest bidder will catapult Judge and Lawyer to the Billionaires'Club.

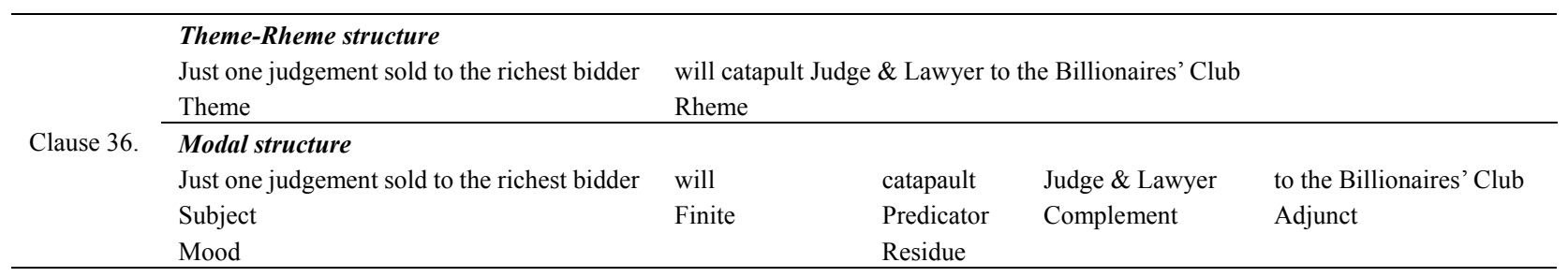

The first clause above (clause 8) is a clause simplex. To realise the clause-as-message function of the clause, the lexico-semantic resources are organized into the Theme (which consists of Theme 1 Shall and Theme $2 I$ ) and the Rheme, which comprises all other constituents of the clause. The clause is an interrogative yes-no clause, so the Theme includes the Finite operator Shall, an interpersonal Theme. But since the Finite operator is not an element in the experiential structure of the clause (Halliday \& Matthiessen, 2014), the Theme extends over to the Subject $I$, which serves as the topical theme. In terms of the modal structure, the Mood is realised by the Finite Shall and the Subject $I$, while the Residue comprises the Predicator element give, Complement element $a$ billion and the Adjunct to each of your paramours the black, the light, the Fanta-yellow. The structure of the Mood is Finite ^ (followed by) Subject, thus realizing a yes-no interrogative.

The second clause (Clause 36) is also a clause simplex, though the Subject Just one judgement sold to the richest bidder contains an instance of embedding (sold to the richest bidder) as post-Head modifier. In terms of the thematic structure, the Subject of the clause Just one judgement sold to the richest bidder is the Theme, the point of departure and the information unit first projected, while all other clausal constituents (including the Predicator will catapult, the Complement Judge and Lawyer and the Adjunct to the Billionaires Club) make-up the Rheme. The Theme here is conflated with the Subject, and it is therefore unmarked. In terms of the Mood structure, the Subject of the clause, Just one judgement sold to the richest bidder and the Finite will constitute the Mood Block while the Residue comprises the Predicator catapault, Complement Judge and Lawyer and the Adjunct to the Billionaires $C l u b$. The modal structure is Subject ^ the Finite, and this structure makes the clause a declarative one.

\section{Results of Analyses and Discussion}

\subsection{Clause Components}

The poem was analysed into 48 clause simplexes. A clause simplex is one that can stand independently and convey complete semantic sense (Dahunsi, 2016) as opposed to a clause complex, where two or more clause are linked together by means of some logico-semantic relation (parataxis and hypotaxis). Some of the clauses are listed below.

f) My Lord, tell me where to keep your bribe.

g) The roof is roundly perforated by termites of graft.

h) Scoundrel vote-riggers romp to electoral victory.

i) All hail our buyable Bench and conniving Bar.

j) For sale to the highest bidder Interlocutory and perpetual injunctions, opulent criminals shop for pliant judges.

\subsection{Thematic Analysis}

The thematic analysis of the poem shows the various themes and the theme types used by the poet to convey the overall message of the poem as well as a clause-by-clause conveyance of meaning. Presented in Table 1 are the details of the themes in the poem. In all, there are ten (10) textual themes, which are used generally as elements of cohesion, and specifically to relate the clauses in which they appear to the preceding clauses. These are or (4 times), and (4 times), and but (2 times). There are two unique patterns in the poet's choices of textual themes in the poem. The first unique pattern is the sequential order of the textual themes. All the four uses of or follow one another sequentially without any other type coming between them (clauses 3,5,7 and 10). All the four (except the last) uses of and follow one another sequentially (clauses 13, 25,33), and the two uses of but also follow each other sequentially (clauses 38 and 43) without any other textual theme type coming between them. The second uniqueness is the fact that all the ten textual themes are conjunctive adjuncts, and none is continuity adjunct (such as oh, no, well, yea etc.). 
Table 1. Identification of topical, interpersonal and textual themes in the poem

\begin{tabular}{|c|c|c|}
\hline Topical Themes & Interpersonal Themes & Textual Themes \\
\hline My Lord (clauses $1,12,14,15,31)$ & do (clauses 2, 3) & or (clauses $3,5,7,10$ ) \\
\hline I (clauses $2,3,4,6,7,8,10,11$ ) & shall (clauses $4,6,7,8,10,11$ ) & and (clauses $13,25,33,44)$ \\
\hline They (clause $9,39,43,46,47$ ) & will (clauses 5) & but (clause 38,43 ) \\
\hline \multicolumn{3}{|l|}{ Lucky bank bosses (clause 13) } \\
\hline \multicolumn{3}{|l|}{ The last hope of the common man (clause 16) } \\
\hline \multicolumn{3}{|l|}{ A terrible plague (clause 17) } \\
\hline \multicolumn{3}{|l|}{ Besieged (clause 18) } \\
\hline \multirow{2}{*}{\multicolumn{3}{|c|}{$\begin{array}{l}\text { Behind the antiquated wig and the slavish glove, the } \\
\text { penguin gown and the obfuscating jargon (clause 19) }\end{array}$}} \\
\hline & & \\
\hline \multicolumn{3}{|l|}{ Behind the rituals and roted rigmaroles (clause 20) } \\
\hline \multicolumn{3}{|l|}{$\begin{array}{l}\text { Behind the prim-and-proper costumes of masquerades } \\
\text { (clause 21) }\end{array}$} \\
\hline \multicolumn{3}{|l|}{$\begin{array}{l}\text { For sale to the highest bidder Interlocutory and } \\
\text { perpetual injunctions (clause 22) }\end{array}$} \\
\hline \multicolumn{3}{|l|}{ Protect (clause 23) } \\
\hline \multicolumn{3}{|l|}{ Enshrine (clause 24) } \\
\hline \multicolumn{3}{|l|}{ Election Petition Tribunals (clause 25) } \\
\hline \multicolumn{3}{|l|}{ Scoundrel vote-riggers (clause 26) } \\
\hline \multicolumn{3}{|l|}{ All (clause 27) } \\
\hline \multicolumn{3}{|l|}{$\begin{array}{l}\text { A million dollars in Their Lordship's bedroom, a } \\
\text { million euros in the parlor closet, countless naira } \\
\text { beneath the kitchen sink (clause 28) }\end{array}$} \\
\hline \multicolumn{3}{|l|}{ The "Temple of Justice" (clause 29) } \\
\hline \multicolumn{3}{|l|}{ The roof (clause 30) } \\
\hline \multicolumn{3}{|l|}{ Judges (clause 32) } \\
\hline \multicolumn{3}{|l|}{ The Chief justice (clause 33) } \\
\hline \multicolumn{3}{|l|}{ Crime (clause 34) } \\
\hline \multicolumn{3}{|l|}{ Corruption (clause 35) } \\
\hline \multicolumn{3}{|l|}{ Just one judgement sold to the richest bidder (clause } \\
\hline \multicolumn{3}{|l|}{ 36) } \\
\hline \multicolumn{3}{|l|}{ The Law, they say, (clause 37) } \\
\hline \multicolumn{3}{|l|}{ The Law in Nigeria (clause 38 ) } \\
\hline \multicolumn{3}{|l|}{ Unhappy (clause 40) } \\
\hline \multicolumn{3}{|l|}{ Come Sunday (clause 41) } \\
\hline \multicolumn{3}{|l|}{ Friday (clause 42) } \\
\hline \multicolumn{3}{|l|}{ dig (clause 44) } \\
\hline \multicolumn{3}{|l|}{ Nigeria (clause 45) } \\
\hline My most honourable Lord (clause 48) & & \\
\hline
\end{tabular}

There are nine interpersonal themes in the poem, all occurring between clause 2 and clause 11. The Interpersonal themes are used to give the clauses where they occur Mood labels. They also make the clauses interrogative as against declaratives or imperatives. The constituents that can function as Interpersonal theme include unfused Finite (can, shall, would, have etc.) and Modal Adjuncts (which include mood adjuncts, vocative adjuncts, polarity adjuncts and comment adjuncts). The observed pattern in the poem is complete choices of unfused Finite, which includes do (2 times), shall (6 times) and will (1 time).

All the clauses have topical themes. These include nominal Subjects such as My Lord (unmarked themes) in clauses 1, 12, 14, 15 and lucky bank bosses (clause 13); pronominal Subjects such as $I$ (in clauses 1, 2, 3, 6, 7, 8, 10 etc.), it (clause 5) and they (clause 9); rankshifted clause as Subject Just one judgement sold to the richest bidder (clause 36). There are instances of marked themes in clauses where the Adjunct element comes first in the information order such as Behind the antiquated wig and the slavish glove, the penguin gown and the obfuscating jargon (clause 19), Behind the rituals and roted rigmaroles (clause 20), Behind the prim-and-proper costumes of masquerades (clause 21), For sale to the highest bidder Interlocutory and perpetual injunctions (clause 22), Come Sunday (clause 43) etc. In clauses 18, 23 and 24, the Predicator elements occupy the (topical) thematic position (Besieged, protect, enshrine) making them marked themes in each case.

One very important feature that makes the thematisation pattern very unique is the recurrent grammatical structure that spans through some groups of clauses in the poem. This is structural parallelism and its predominance in the 
poem has great thematic importance. The thematic structure Theme (= interpersonal + topical) followed by Rheme (with two examples below) is recurrent in nine (9) clauses (clauses 2, 3, 4, 5, 6, 7, 8, 10 and 11). Two examples of this type of structure are shown below.

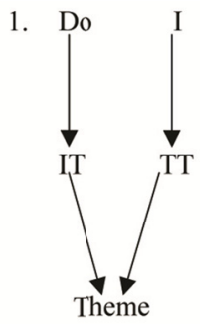

2. Will it

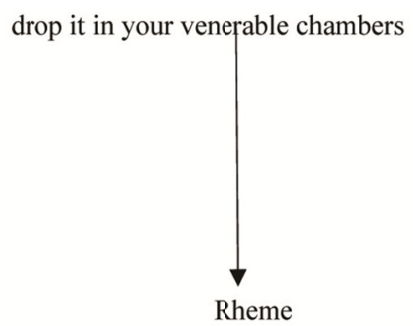

breathe better in the septic tank since money can ... the smelliest crime.
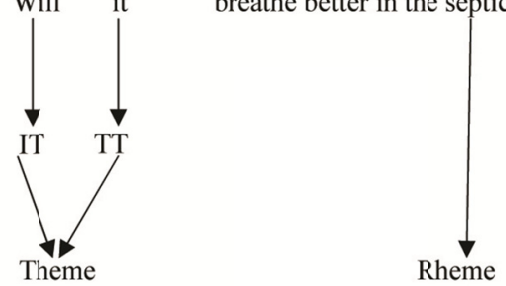

The recurrent thematic pattern and structural parallelism in these clauses are observed to be a deliberate ploy of the poet to make the general issue of bribery enormously prominent, but with reinforced emphasis on the perceived compulsion on the part of the accused person to give. This is evident in the strong modal verbs used including shall $I$ and $\underline{d o} I$ at different times as the interpersonal and topical themes in all the nine clauses. In all the nine clauses too, the Rheme is constituted essentially by locational adjuncts that indicate where the supposed bribe is to be kept. These include in your venerable chambers, in the septic tank, your immaculate mansion, in the capacious water tank in your well laundered backyard, up the attic between the ceiling and your lofty roof etc. The poet's lexical choices here are aimed at exposing and ridiculing the judges and the unimaginable, illicit and barbaric ways of keeping their loot to avoid public knowledge.

Another recurrent thematic pattern in the poem is the markedness of the themes in some successive clauses. Clauses 19, 20, 21 and 22 for example have the topical theme realised by Adjunct elements. These include:

- Behind the antiquated wig and the slavish glove, the penguin gown and the obfuscating jargon is a rot and riot whose stench ... (clause 19).

- $\quad$ Behind the rituals and roted rigmaroles old antics connive with new tricks (clause 20).

- $\quad$ Behind the prim-and-proper costumes of masquerades corruption stands, naked... (clause 21).

- $\quad$ For sale to the highest bidder Interlocutory and perpetual injunctions opulent criminals shop for... (clause 22).

With the recurring thematisation pattern in the four clauses above, the poet presents the professional robe of judges, which looks similar globally and which should normally symbolise purity, fairness, and objectivity. He, however, juxtaposes each theme (positive symbolism) with a contradictory experience or phenomenon (negative symbolism), which foregrounds some kind of irony. In clause 19, the antiquated wig and the slavish glove... is followed by a rot and riot; in clause 20, the rituals and roted rigmaroles is followed by old antics; the prim-and-proper costumes juxtaposed with corruption stands, naked. An instance of clustered theme, which is characterised by some structural repetition is observed in clause 28, where three different sub-constituents make up the topical theme. These are A million dollars in their Lordship's bedroom, a million euros in the parlor closet, countless naira beneath the kitchen sink. What this foregrounds is the fact that the loot of Nigerian judges (as presented in the poem) is in huge quantities and different currencies (dollars, euros, naira etc.), and these are kept in ridiculous places that cannot be easily traced.

The patterns of thematisation adopted by the poet enables him to bring to thematic prominence the major issues of concern and worry to an average Nigerian who has always thought the judges and the courts of law should be neutral and devoid of corruption. These include the satirized (powerful) My Lord, My Most Honourable Lord as 
against the dramatized imaginary (powerless) accused person $I$; the places where the great quantum of illicitly gotten wealth of the judges were kept such as The roof of judges' houses (clause 30); the satirized legal costumes of judges such as Behind the antiquated wig and the slavish glove... (clause 19), Behind the rituals and roted rigmaroles (clause 20), Behind the prim-and-proper costumes of masquerades (clause 21) and the bastardised electoral system that leads to politicians' fraud and judges' corruption-prone miscarriage of justice in favour of the rich such as (in bold) Election Petition Tribunals (clause 25) and Scoundrel vote-riggers (clause 26).

\subsubsection{Paradigmatic Choices, Thematisation and the Realization of Authorial Intention}

The intention of the poet in the poem is to expose the corrupt practices of judges in Nigeria. In the course of that, however, the poet ridicules the judges, lampoons them and condemns such heinous acts, which fell far beneath the expectations of the Nigerian and global public. This authorial intention was achieved through conscious lexical selections and paradigmatic choices, and by structuring the lexical choices into units that fit into the thematic structures of the poem. Four broad issues are presented in the poem. These are the issue of corruption in the judiciary, the corrupt judges, the unconventional ways of keeping their (the judges') loot, and the effect of these heinous acts on the well-being of Nigeria. The poet's paradigmatic choices are strategic. In painting corruption as heinous, he chooses words with negative denotation and connotation (such as your bribe, corruption, heavy booty, this sudden booty, the loot, insolent impunity, injunctions for sale, a fraction of the loot etc.).

In the poet's presentation of the judges, there is some irony in his choices of words. He calls the judges my Lord and my most honourable Lord repeatedly. This is a literary ploy and an irony to lampoon the judges who are expected to be honourable but are "dishonourable" in conduct. To further reinforce his presentation of the dishonourable conduct of the judges, the poet chooses series of negative epithets (such as your paramours, rapacious judges, venal lawyers, buyable Bench, conniving bar, pliant judges) and refers to them as jobbers and Monsters of Mammon. Each time the poet repeats some words in the poem, it is a rhetorical strategy for emphacis, and in such cases, the words have both denotative and figurative uses.

For example, the repeated uses of Behind (in clauses 19, 20 and 21) is not merely a physical locational description but is a way of visualizing the giving and taking of bribe, which in the Nigerian context, is understood to be money taken from behind (because it is illegal and illicit). This is why the poet thematises (marked theme) the Adjunct element with behind as headword in each of the three clauses. In his presentation of the judges' properties, the poet uses some adjectives (such as venerable chambers, immaculate mansion, capacious water tank, well laundered backyard, lofty roof etc.). The intention here is to make these properties questionable in terms of the legitimacy of the source from which they were acquired. To describe the effect of a corruption-ridden judiciary on the nation, the poet employs some metaphors, by describing the country as a huge corpse, and by referring to corruption as $a$ terrible plague that has besieged the land and as some stench choking the land.

In essence, the poet has carefully made lexical and paradigmatic choices to express the messages and meanings he intends to convey. He uses negative words to express negative experience about corruption and the judges. He employs the use of derogatory epithets to describe the judges, and chooses superfluous adjectives to describe questionable things (like judges' properties and possible places where they keep their loot). All these paradigmatic choices are systematically combined together to form groups (Nominal groups, Verbal groups, Adverbial groups etc.) and are thematically structured to foreground aspects of poetic meanings and messages that need prominence.

\subsection{Mood Analysis}

The poem is composed first as an imaginary dialogue between a judge and an accused person, and later as a monologue with the poet expressing his feelings and opinions on Nigerian judges and the Nigerian judiciary. The poet's voice represents the imaginary accused person while the imaginary judge has no voice. With the first part of the poem seen as a communicative exchange between two persons, some relationship is enacted through language in the course of the exchange. In clauses 2 to 11, the poet takes on the speech role of giving, with information as the commodity of exchange. This is why he uses questions as the move type, to ask for some information from the imaginary listener (the judge). Though the structure of the clauses here show that the poet is asking for information from the judge, the poet is also functionally seeking direction and permission from the judge as to where the bribe should be put. In the remaining part of the poem, the poet takes on the speech role, also of giving, and with information as commodity of exchange between him and the reader. However, he uses statements as the move type, to express his feelings and opinions about the satirized judges and the Nigerian judiciary.

It is the Mood in the clauses that realise this relationship. All the 48 clauses in the poem contain the modal element (Subject and Finite), thus making the Mood indicative. From this broad type, the variation of the modal element produces different clause types: declaratives, yes-no interrogatives and Wh-interrogatives. The poet employs the Finite ^ (followed by) Subject modal structure for nine (9) clauses (clauses 2 to 8, and clauses 10 and 11). This 
structure generates yes-no interrogatives such as Do I drop it... (clause 2), do I carry the booty... (clause 3), shall I burry it... (clause 4), will it breathe better... (clause 5) etc. The poet also chooses the present forms of the Finite in each case (shall, will, do etc.). He also employs the Subject ${ }^{\wedge}$ Finite structure, which realizes the declarative clauses in the poem. A total of thirty-four (34) clauses have this structure, with examples in They will surely know... (clause 9), My Lord, it will take the fastest machine... (clause 12), lucky bank bosses may help themselves (clause 15) etc.

The Finite elements are realised in two different ways: one, by making choices of Finite verbal operators (shall, a positive, future temporal operator; and will, a positive, median modal operator); and two, the fusion of the Finite element with the Predicator with examples in crime (Subject) pays (Finite fused with Predicator pays - clause 34), They (Subject) kill (Finite fused with Predicator kill—clause 39). The poet's consistent use of the present forms of the Finite (and Predicator, for example: old antics connive, corruption stands, a terrible plaque bestrides, lucky bank bosses may help, shall I, will it, etc.) is also noteworthy. These are paradigmatic choices to create some sense of immediacy and expectations, as against the past forms of the Finite, which would have signaled some remoteness and staleness of actions in the poem. The present tense form of the verbal groups in the poem also indicates consistency of continuity of the judges' corrupt habits.

The poet has limited himself to the choices of interrogatives and declaratives, and has realised these by varying the Subject-Finite order. This Subject-Finite variation leads to different grammatical and clausal structures, and these structural differences give way to differences in meanings, thus differentiating for example questions from commands, or statements from questions. Obviously, in terms of the Mood structure, the poem has two different sections with the first section (clauses 2-11) being only for a list of questions for the imaginary judge, questions that ridicule and mock the judge for being corrupt, and most importantly for the kinds of places where corrupt judges were alleged to have been keeping their ill-gotten wealth (venerable chambers, immaculate mansion, capacious water tank, laundered backyard, septic tank etc.).

The interrogative clauses in this part of the poem also indicates a master-servant relationship between the accused person (who is shown as helpless and who needs some favour from the judges) and the judges (who are presented as being in a position to help the accused). From clauses 12 to 43, the poet makes declarations on the judges, the legal system, the shocking compromises in the judiciary and the effect of a corrupt judicial system on the nation. To be able to convey these messages and meanings, the poet makes paradigmatic choices at each level of clause constituents, and systematically arranges these choices in linear syntactic structures to convey different kinds of meaning for each clause in the poem.

\section{Conclusion}

A textual analysis of the poem titled "My Lord, Please Tell Me Where to Keep Your Bribe" has been carried out using the Systemic Functional Grammar as analytical framework. With focus on two (textual and interpersonal) of the three strands of meaning (ideational, interpersonal and textual) conveyed in the clause, SFG has enabled us to unravel how meanings are made in the poem by making lexical and paradigmatic choices and arranging them into different kinds of grammatical structures to convey different types of meanings. An exploration of the grammar of textual meaning in the poem provided useful insight into how the information and messages in each clause have been organized in a way that clearly shows which chunk of information is given thematic prominence. The patterns of thematisation have shown the poet's choices of the textual, interpersonal and topical themes. While the textual themes help to situate and relate clauses in contexts of occurrence, the interpersonal themes help to assign Mood label to clauses where they occur, thus ultimately enabling the definition of role and social relationship between the persons involved in the dialogue. The topical themes are the elements of the clause that carry a Transitivity function (of circumstance, actor etc.), and each of the clauses in the poem has a topical theme. An exploration of the grammar of interpersonal meaning in the poem also provided insight into how paradigmatic choices are made and how such choices are arranged into different grammatical structures to make different semantic senses. Through the Mood structure analysis, we were able to see how different grammatical structures (Finite-Subject variations) help to enact social relationships and how speech roles are assigned, leading to the discovery of both questions and statements as the basic exchange moves used in the poem.

\section{References}

Beaugrande, R., \& Dressler, W. (1981). Introduction to text linguistics. London, England: Routledge.

Cap, P., \& Okulska, U. (Eds.). (2013). Analyzing Genres in Political Communication: Theory and Practice, 50. Amsterdam: John Benjamins Publishing. https://doi.org/10.1075/dapsac.50

Dahunsi, T. N. (2016). Grammar and gender: A comparative study of the integration and organisation of meanings 
in selected male and female-authored proseworks. International Journal of Applied Linguistics and English Literature, 6(1), 275-285. https://doi.org/10.7575/aiac.ijalel.v.6n.1p.275

Eggins, S. (2004). An introduction to systemic functional linguistics (2nd ed.). London, England: Bloomsbury Publishing Plc.

Fontaine, L. (2013). Analysing English grammar: A systemic functional introduction. Cambridge, England: Cambridge University Press.

Halliday, M. A. K. (1985). Systemic background. In "Systemic perspectives on discourse, Vol. 1: Selected theoretical papers" from the Ninth International Systemic Workshop. In J. D. Benson \& W. S. Greaves (Eds.), Ablex. Reprinted in Full in Volume 3 in The Collected Works of M. A. K. Halliday (p. 188). London, England: Continuum.

Halliday, M. A. K. (1994). Introduction to functional grammar (2nd ed.). London, England: Edward Arnold.

Halliday, M. A. K., \& Hasan, R. (1976). Cohesion in English. London, England: Longman.

Halliday, M. A. K., \& Matthiessen, C. M. I. M. (2014). Halliday's introduction to functional grammar (4th ed.). London, England: Routledge.

Hasan, R. (2009). The place of context in a systemic functional model. Continuum Companion to Systemic Functional Linguistics, 166-189.

Hutchby, I., \& Wooffitt, R. (2008). Conversation analysis. Cambridge, England: Polity Press.

Hymes, D. (1972). Toward ethnography of communication: the analysis of communicative events. In P. Giglioli (Ed.), Language and Social Context (pp. 21-43). Harmondsworth: Penguin. (excerpts from Hymes, D. (1966) Introduction: toward ethnographies of Communication. American Anthropologists, 66(6), 12-25.)

Hymes, D. (1974). Toward ethnographies of communication. Foundations in Sociolinguistics: an ethnographic approach (pp. 145-178). Philadephia: University of Pennsylvania Press.

Kazemian, B., \& Hashemi, S. (2014). Nominalizations in scientific and political genres: A systemic functional linguistics perspective. International Journal of Humanities and Social Sciences (IJHSS), 3(2), 211-228.

Kazemian, B., \& Hashemi, S. (2014). Critical discourse analysis of Barack Obama's 2012 speeches: Views from systemic functional linguistics and rhetoric. Theory and Practice in Language Studies (TPLS), 4(6), 1178-1187. https://doi.org/10.4304/tpls.4.6.1178-1187

Kazemian, B., Behnam, B., \& Ghafoori, N. (2013). Ideational grammatical metaphor inscientific texts: a Hallidayan perspective. International Journal of Linguistics, 4(4), 146-168. https://doi.org/10.5296/ijl.v5i4.4192

Noor, M., Ali, M., Muhabat, F., \& Kazemian, B. (2015). Systemic Functional Linguistics Mood Analysis of the Last Address of the Holy Prophet (PBUH). International Journal of Language and Linguistics. Special Issue: Critical Discourse Analysis, Rhetoric, and Grammatical Metaphor in Political and Advertisement Discourses, 4(1-1), 1-9. https://doi.org/10.2139/ssrn.2604000

Nur, S. (2015). Analysis of interpersonal metafunction in public speeches: a case study of Nelson Mandela's presidential inauguration speech. The International Journal of Social Sciences, 30(1), 52-63.

Schiffrin, D. (2007). Approaches to discourse. Oxford, England: Blackwell Publishing.

Thompson, G. (2004). Introducing functional grammar (2nd ed.). London, England: Edward Arnold.

Zhou, Q., \& Kazemian, B. (2015). A Rhetorical Identification Analysis of English Political Public Speaking: John F. Kennedy's Inaugural Address. International Journal of Language and Linguistics. Special Issue: Critical Discourse Analysis, Rhetoric, and Grammatical Metaphor in Political and Advertisement Discourses, 4(1-1), 10-16. 


\section{Appendix A}

Full Text of the Poem Analysed: My Lord, Tell Me Where to Keep Your Bribe (By Niyi Osundare)

My Lord,

Please tell me where to keep your bribe?

Do I drop it in your venerable chambers?

Or carry the heavy booty to your immaculate mansion?

Shall I burry it in the capacious water tank

In your well laundered backyard?

Or will it breathe better in the septic tank

Since money can deodorize the smelliest crime

Shall I haul it up the attic

Between the ceiling and your lofty roof?

Or shall I conjure the walls to open up

And swallow this sudden bounty from your honest labour?

Shall I give a billion to each of your paramours

The black, the light, the fanta-yellow?

They will surely know how to keep the loot

In places too remote for the sniffing dog.

Or shall I use the particluars

Of your anonymous maidservants and manservants

With their names on overflowing bank accounts

While they famish like ownerless dogs.

Shall I haul it up to your village

In the valley behind seven mountains

Where potholes swallow up the hugest jeep

And penury leaves a scar on every house.

My Lord

It will take the fastest machine

Many, many days to count this booty; and lucky bank bosses

May help themselves to a fraction of the loot.

My Lord

Tell me where to keep your bribe? 
My Lord

Tell me where to keep your bribe?

The "last hope of the common man"

Has become the last bastion of the criminally rich

A terrible plague bestrides the land

Besieged by rapacious judges and venal lawyers

Behind the antiquated wig

And the slavish glove

The penguin gown and the obfuscating jargon

Is a rot and riot whose stench is choking the land

Behind the rituals and roted rigmaroles

Old antics connive with new tricks

Behind the prim-and-proper costumes of masquerades

Corruption stands, naked, in its insolent impunity

For sale to the highest bidder

Interlocutory and perpetual injunctions

Opulent criminals shop for pliant judges

Protect the criminal, enshrine the crime

And the Election Petition Tribunals

Ah bless those goldmines and bottomless booties!

Scroundrel vote-riggers romp to electoral victory

All hail our buyable Bench and conniving Bar

A million dollars in Their Lordship's bedroom

A million euros in the parlor closet

Countless naira beneath the kitchen sink

Our courts are fast running out of Ghana-must-go's

The "temple of justice"

Is broken in every brick

The roof is roundly perforated

By termites of graft

My Lord

Tell me where to keep your bribe?

Judges doze in the courtroom

Having spent all night, counting money and various "gifts"

And the Chief Justice looks on with tired eyes 
As corruption usurps his gavel

Crime pays in this country

Corruption has its handsome rewards

Just one judgement sold to the richest bidder

Can catapult Judge and Lawyer to the Billionaires' Club

The Law, they say, is an ass

Sometimes fast, cometimes slow

But the Law in Nigeria is a vulture

Fat on the cash-and-carry carrion of murdered Conscience

Won gb'ebif'alare

Won gb'are f'elebi**

They kill our trust in the common good

These Monsters of Mammon in their garish gowns

Unhappy the land

Where jobbers are judges

Where Impunity walks the streets

Like a large, invincible Demon

Come Sunday, they troop to the church

Friday, they mouth their mantra in pious mosques

But they pervert Justice all week long

And dig us deeper into the hellish hole

Nigeria is a huge corpse

With milling maggots on its wretched hulk

They prey every day, they prey every night

For the endless decomposition of our common soul

\section{My Most Honourable Lord}

Just tell me where to keep your bribe

Source: http://saharareporters.com/2016/10/26/my-lord-tell-me-where-keep-your-bribe-niyi-osundare 


\section{Appendix B}

\section{Clause-by-Clause Analysis of the Poem}

\begin{tabular}{|c|c|c|c|c|c|}
\hline \multirow{8}{*}{ Clause 1.} & \multicolumn{5}{|c|}{ Thematic analysis } \\
\hline & My Lord & \multicolumn{4}{|c|}{ please tell me where to keep your bribe } \\
\hline & topical & \\
\hline & Theme & \multicolumn{4}{|l|}{ Rheme } \\
\hline & \multicolumn{5}{|c|}{ Mood analysis } \\
\hline & My Lord & please & tell & me & where to keep your bribe \\
\hline & Subject & & Finite & Complement $^{1}$ & Complement $^{2}$ \\
\hline & \multicolumn{3}{|l|}{ Mood } & \multicolumn{2}{|l|}{ Residue } \\
\hline
\end{tabular}

\begin{tabular}{|c|c|c|c|c|c|}
\hline \multirow{8}{*}{ Clause 2.} & \multicolumn{5}{|c|}{ Thematic analysis } \\
\hline & Do & $\mathrm{I}$ & \multicolumn{3}{|c|}{ drop it in your venerable chambers? } \\
\hline & interpersonal & topical & \multicolumn{3}{|l|}{ Rheme } \\
\hline & Theme & & \multicolumn{3}{|l|}{ Rheme } \\
\hline & \multicolumn{5}{|l|}{ Mood analysis } \\
\hline & Do & $\mathrm{I}$ & drop & it & in your venerable chambers? \\
\hline & Finite & Subject & Predicator & Complement & Adjunct \\
\hline & \multicolumn{2}{|l|}{ Mood } & \multicolumn{3}{|l|}{ Residue } \\
\hline
\end{tabular}

\begin{tabular}{|c|c|c|c|c|c|c|}
\hline \multirow{8}{*}{ Clause 3.} & \multicolumn{6}{|c|}{ Thematic analysis } \\
\hline & or & do & I & \multicolumn{3}{|c|}{ carry the booty to your immaculate mansion } \\
\hline & textual & interpersonal & topical & & & \\
\hline & \multicolumn{3}{|l|}{ Theme } & \multicolumn{3}{|l|}{ Rheme } \\
\hline & \multicolumn{6}{|c|}{ Mood analysis } \\
\hline & or & do & I & carry & the booty & to your immaculate mansion \\
\hline & (Conjunct) & Finite & Subject & Predicator & Complement & Adjunct \\
\hline & & \multicolumn{2}{|l|}{ Mood } & \multicolumn{3}{|l|}{ Residue } \\
\hline
\end{tabular}

\begin{tabular}{|c|c|c|c|c|c|c|}
\hline \multirow{8}{*}{ Clause 4.} & \multicolumn{6}{|c|}{ Thematic analysis } \\
\hline & shall & $\mathrm{I}$ & \multicolumn{4}{|c|}{ burry it in the capacious water tank in your well laundered backyard. } \\
\hline & interpersonal & topical & \multirow{2}{*}{\multicolumn{4}{|c|}{ Rheme }} \\
\hline & \multicolumn{2}{|l|}{ Theme } & & & & \\
\hline & \multicolumn{6}{|c|}{ Mood analysis } \\
\hline & shall & I & burry & it & in the capacious water tank & in your well laundered \\
\hline & Finite & Subject & Predicator & Complement & Adjunct $^{1}$ & Adjunct $^{2}$ \\
\hline & \multicolumn{2}{|l|}{ Mood } & \multicolumn{4}{|l|}{ Residue } \\
\hline
\end{tabular}

\begin{tabular}{|c|c|c|c|c|c|c|c|}
\hline \multirow{8}{*}{ Clause 5.} & \multicolumn{7}{|c|}{ Thematic analysis } \\
\hline & or & will & it & \multicolumn{4}{|c|}{ breathe better in the septic tank since money can deodorize the smelliest crime. } \\
\hline & textual & interpersonal & topical & & & & \\
\hline & \multicolumn{3}{|l|}{ Theme } & \multicolumn{4}{|l|}{ Rheme } \\
\hline & \multicolumn{6}{|c|}{ Mood analysis } & \\
\hline & or & will & it & breathe & better & in the septic tank & $\begin{array}{l}\text { since money can deodorize } \\
\text { the smelliest crime. }\end{array}$ \\
\hline & (Conjunct) & Finite & Subject & Predicator & Complement & Adjunct $^{1}$ & Adjunct $^{2}$ \\
\hline & & Mood & & Residue & & & \\
\hline
\end{tabular}

\begin{tabular}{|c|c|c|c|c|c|c|}
\hline \multirow{8}{*}{ Clause 6.} & \multicolumn{6}{|c|}{ Thematic analysis } \\
\hline & Shall & I & \multicolumn{4}{|c|}{ haul it up the attic between the ceiling and your lofty roof } \\
\hline & interpersonal & topical & & & & \\
\hline & \multicolumn{2}{|l|}{ Theme } & \multicolumn{4}{|l|}{ Rheme } \\
\hline & \multicolumn{5}{|l|}{ Mood analysis } & \\
\hline & shall & $\mathrm{I}$ & haul & it & up the attic & between the ceiling and your lofty roof \\
\hline & Finite & Subject & Predicator & Complement & Adjunct $^{1}$ & Adjunct $^{2}$ \\
\hline & \multicolumn{2}{|l|}{ Mood } & \multicolumn{4}{|l|}{ Residue } \\
\hline
\end{tabular}




\begin{tabular}{|c|c|c|c|c|c|c|}
\hline \multirow{8}{*}{ Clause 7.} & \multicolumn{6}{|c|}{ Theme-Rheme structure } \\
\hline & or & shall & I & \multicolumn{3}{|c|}{$\begin{array}{l}\text { conjure the walls to open up and swallow this sudden bounty from your } \\
\text { honest labour }\end{array}$} \\
\hline & textual & interpersonal & topical & \multirow{2}{*}{\multicolumn{3}{|c|}{ Rheme }} \\
\hline & \multicolumn{3}{|l|}{ Theme } & & & \\
\hline & \multicolumn{6}{|c|}{ Modal structure } \\
\hline & or & shall & I & conjure & the walls & $\begin{array}{l}\text { to open up and swallow this bounty } \\
\text { from your honest labour. }\end{array}$ \\
\hline & & Finite & Subject & Predicator & Complement $^{1}$ & Complement $^{2}$ \\
\hline & & \multicolumn{2}{|l|}{ Mood } & \multicolumn{3}{|l|}{ Residue } \\
\hline
\end{tabular}

\begin{tabular}{|c|c|c|c|c|c|}
\hline \multirow{8}{*}{ Clause 8.} & \multicolumn{5}{|c|}{ Thematic analysis } \\
\hline & shall & $\mathrm{I}$ & \multicolumn{3}{|c|}{ give a billion to each of your paramours the black, the light, the Fanta-yellow } \\
\hline & interpersonal & topical & \multirow{2}{*}{\multicolumn{3}{|c|}{ Rheme }} \\
\hline & \multicolumn{2}{|l|}{ Theme } & & & \\
\hline & \multicolumn{5}{|c|}{ Mood analysis } \\
\hline & shall & I & give & a billion & $\begin{array}{l}\text { to each of your paramours the black, the } \\
\text { light, the Fanta-yellow. }\end{array}$ \\
\hline & Finite & Subject & Predicator & Complement & Adjunct \\
\hline & \multicolumn{2}{|l|}{ Mood } & \multicolumn{3}{|l|}{ Residue } \\
\hline
\end{tabular}

\begin{tabular}{|c|c|c|c|c|c|c|}
\hline \multirow{8}{*}{ Clause 9.} & \multicolumn{6}{|c|}{ Thematic analysis } \\
\hline & They & \multicolumn{5}{|c|}{ will surely know how to keep the loot in places too remote for the sniffing dog. } \\
\hline & topical & & & & & \\
\hline & Theme & \multicolumn{5}{|c|}{ Rheme } \\
\hline & \multicolumn{6}{|c|}{ Mood analysis } \\
\hline & They & will & surely & know & how to keep the loot & in places too remote for the sniffing dog \\
\hline & Subject & Finite & Adjunct $^{1}$ & Predicator & Complement & Adjunct $^{2}$ \\
\hline & \multicolumn{2}{|l|}{ Mood } & \multicolumn{4}{|l|}{ Residue } \\
\hline
\end{tabular}

\begin{tabular}{|c|c|c|c|c|c|c|}
\hline \multirow{8}{*}{ Clause 10.} & \multicolumn{6}{|c|}{ Thematic analysis } \\
\hline & or & shall & I & \multicolumn{3}{|c|}{$\begin{array}{l}\text { use the particulars of your anonymous maidservants and manservants with their names on } \\
\text { overflowing bank accounts while they famish like ownerless dogs }\end{array}$} \\
\hline & textual & interpersonal & topical & \\
\hline & \multicolumn{3}{|l|}{ Theme } & & & \\
\hline & \multicolumn{5}{|c|}{ Mood analysis } & \\
\hline & or & shall & I & use & $\begin{array}{l}\text { the particulars of your } \\
\text { anonymous maidservants and } \\
\text { manservants }\end{array}$ & $\begin{array}{l}\text { with their names on overflowing bank } \\
\text { accounts, while they famish like } \\
\text { ownerless dogs }\end{array}$ \\
\hline & \multirow[t]{2}{*}{ (Conjunct) } & Finite & Subject & Predicator & Complement & Adjunct \\
\hline & & Mood & & \multicolumn{3}{|l|}{ Residue } \\
\hline
\end{tabular}

\begin{tabular}{|c|c|c|c|c|c|}
\hline \multirow{8}{*}{ Clause 11.} & \multicolumn{5}{|c|}{ Thematic analysis } \\
\hline & shall & I & \multicolumn{3}{|c|}{$\begin{array}{l}\text { Haul it all to your village in the valley behind seven mountains where potholes swallow up } \\
\text { the hugest jeep and Penury leaves a scar on every house. }\end{array}$} \\
\hline & interpersonal & topical & \multicolumn{3}{|l|}{+2} \\
\hline & \multicolumn{2}{|l|}{ Theme } & \multicolumn{3}{|l|}{ Rheme } \\
\hline & \multicolumn{5}{|c|}{ Mood analysis } \\
\hline & shall & I & haul & it all & $\begin{array}{l}\text { to your village in the valley behind seven mountains where } \\
\text { potholes swallow up the hugest jeep and Penury leaves a } \\
\text { scar on every house. }\end{array}$ \\
\hline & Finite & Subject & Predicator & Complement & Adjunct \\
\hline & \multicolumn{2}{|l|}{ Mood } & \multicolumn{3}{|l|}{ Residue } \\
\hline
\end{tabular}




\begin{tabular}{|c|c|c|c|c|c|c|}
\hline \multirow{8}{*}{ Clause 12.} & \multicolumn{6}{|c|}{ Thematic analysis } \\
\hline & My Lord & \multicolumn{5}{|c|}{ it will take the fastest machine many, many days to count this booty } \\
\hline & topical & & & & & \\
\hline & Theme & \multicolumn{5}{|l|}{ Rheme } \\
\hline & \multicolumn{6}{|l|}{ Mood analysis } \\
\hline & My Lord & it & will & take & the fastest machine & $\begin{array}{l}\text { many, many days to count this } \\
\text { booty }\end{array}$ \\
\hline & $\begin{array}{l}\text { (non-thematic } \\
\text { Subject) }\end{array}$ & $\begin{array}{l}\text { (Thematic } \\
\text { Subject) }\end{array}$ & Finite & Predicator & Complement & Adjunct \\
\hline & Residue & \multicolumn{2}{|l|}{ Mood } & \multicolumn{3}{|l|}{ Residue } \\
\hline
\end{tabular}

\begin{tabular}{|c|c|c|c|c|c|c|}
\hline \multirow{8}{*}{ Clause 13.} & \multicolumn{6}{|c|}{ Thematic analysis } \\
\hline & and & lucky bank bosses & \multicolumn{4}{|c|}{ may help themselves to a fraction of the loot } \\
\hline & textual & topical & & & & \\
\hline & \multicolumn{2}{|l|}{ Theme } & \multicolumn{4}{|l|}{ Rheme } \\
\hline & \multicolumn{6}{|c|}{ Mood analysis } \\
\hline & and & lucky bank bosses & may & help & themselves & to a fraction of the loot \\
\hline & & Subject & Finite & Predicator & Complement & Adjunct \\
\hline & & \multicolumn{2}{|l|}{ Mood Block } & \multicolumn{3}{|l|}{ Residue } \\
\hline
\end{tabular}

\begin{tabular}{|c|c|c|c|c|}
\hline \multirow{8}{*}{ Clause 14.} & \multicolumn{4}{|c|}{ Thematic analysis } \\
\hline & My Lord & \multicolumn{3}{|c|}{ tell me where to keep your bribe } \\
\hline & topical & & & \\
\hline & Theme & \multicolumn{3}{|l|}{ Rheme } \\
\hline & \multicolumn{4}{|c|}{ Mood analysis } \\
\hline & My Lord & tell & me & where to keep your bribe \\
\hline & Subject & (Fused) Finite & Complement & Adjunct \\
\hline & \multicolumn{2}{|c|}{ Mood (with won't you as Mood tag) } & \multicolumn{2}{|l|}{ Residue } \\
\hline
\end{tabular}

\begin{tabular}{|c|c|c|c|c|}
\hline \multirow{8}{*}{ Clause 15.} & \multicolumn{4}{|c|}{ Thematic analysis } \\
\hline & My Lord & \multicolumn{3}{|c|}{ tell me where to keep your bribe } \\
\hline & topical & & & \\
\hline & Theme & \multicolumn{3}{|l|}{ Rheme } \\
\hline & \multicolumn{4}{|c|}{ Mood analysis } \\
\hline & My Lord & tell & me & where to keep your bribe \\
\hline & Subject & Predicator & Complement & Adjunct \\
\hline & \multicolumn{2}{|c|}{ Mood (with won't you as Mood tag) } & \multicolumn{2}{|l|}{ Residue } \\
\hline
\end{tabular}

\begin{tabular}{|c|c|c|c|c|}
\hline \multirow{8}{*}{ Clause 16.} & \multicolumn{4}{|l|}{ Thematic analysis } \\
\hline & The "last hope of the common man" & \multicolumn{3}{|c|}{ has become the last bastion of the criminally rich } \\
\hline & topical & & & \\
\hline & Theme & \multicolumn{3}{|l|}{ Rheme } \\
\hline & \multicolumn{4}{|l|}{ Mood analysis } \\
\hline & The "last hope of the common man" & has & become & the last bastion of the criminally rich \\
\hline & Subject & Finite & Predicator & Complement \\
\hline & \multicolumn{2}{|l|}{ Mood } & \multicolumn{2}{|l|}{ Residue } \\
\hline
\end{tabular}

Clause 17.

\begin{tabular}{|l|l|l|}
\hline \multicolumn{2}{|l|}{ Theme-Rheme structure } & \multicolumn{2}{l|}{} \\
\hline A terrible plague & bestrides the land \\
\hline topical & \multicolumn{2}{l|}{} \\
\hline Theme & Rheme \\
\hline Modal structure & bestrides & the land \\
\hline A terrible plague & (Fused) Finite & Complement \\
\hline Subject & & Residue \\
\hline \multicolumn{2}{|c|}{ Mood } &
\end{tabular}




\begin{tabular}{|c|c|c|c|c|}
\hline \multirow{8}{*}{ Clause 18.} & \multicolumn{4}{|c|}{ Theme-Rheme structure } \\
\hline & besieged & \multicolumn{3}{|c|}{ by rapacious judges and venal lawyers } \\
\hline & topical & & & \\
\hline & Theme & \multicolumn{3}{|l|}{ Rheme } \\
\hline & \multicolumn{4}{|l|}{ Modal structure } \\
\hline & (The land) & (is) & besieged & by rapacious judges and venal lawyers \\
\hline & (Elliptical Subject) & (Elliptical Finite) & Predicator & Adjunct \\
\hline & \multicolumn{2}{|l|}{ Elliptical Mood } & \multicolumn{2}{|l|}{ Residue } \\
\hline
\end{tabular}

\begin{tabular}{|l|l|l|l|}
\hline \multirow{4}{*}{ Clause 19. } & \multicolumn{2}{|l|}{ Theme-Rheme structure } \\
\cline { 2 - 4 } & $\begin{array}{l}\text { Behind the antiquated wig and the slavish glove, the } \\
\text { penguin gown and the obfuscating jargon }\end{array}$ & \multicolumn{2}{|l|}{ is a rot and riot whose stench is choking the land } \\
\cline { 2 - 4 } & topical & \multicolumn{2}{|l|}{ Rheme } \\
\cline { 2 - 4 } & Theme & a rot and riot whose stench is choking the land \\
\cline { 2 - 4 } & Modal structure & Finite & Subject \\
\cline { 2 - 3 } & $\begin{array}{l}\text { Behind the antiquated wig and the slavish glove, the } \\
\text { penguin gown and the obfuscating jargon }\end{array}$ & is & Mood \\
\cline { 2 - 3 } & Adjunct & Residue & \\
\cline { 2 - 4 } & &
\end{tabular}

\begin{tabular}{|c|c|c|c|c|}
\hline \multirow{8}{*}{ Clause 20.} & \multicolumn{4}{|l|}{ Thematic analysis } \\
\hline & Behind the rituals and roted rigmaroles & \multicolumn{3}{|c|}{ old antics connive with new tricks } \\
\hline & topical & & & \\
\hline & Theme (marked) & \multicolumn{3}{|l|}{ Rheme } \\
\hline & \multicolumn{4}{|l|}{ Mood analysis } \\
\hline & Behind the rituals and roted rigmaroles & old antics & connive & with new tricks \\
\hline & Adjunct $^{1}$ & Subject & (Fused) Finite & Adjunct $^{2}$ \\
\hline & Residue & \multicolumn{2}{|l|}{ Mood } & Residue \\
\hline
\end{tabular}

\begin{tabular}{|c|c|c|c|c|c|}
\hline \multirow{8}{*}{ Clause 21.} & \multicolumn{5}{|l|}{ Thematic analysis } \\
\hline & $\begin{array}{l}\text { Behind the prim-and-proper costumes of } \\
\text { masquerades }\end{array}$ & \multicolumn{4}{|c|}{ corruption stands, naked, in its insolent impunity } \\
\hline & \multicolumn{5}{|l|}{ topical } \\
\hline & Theme (marked) & \multicolumn{4}{|l|}{ Rheme } \\
\hline & \multicolumn{5}{|l|}{ Mood analysis } \\
\hline & $\begin{array}{l}\text { Behind the prim-and-proper costumes of } \\
\text { masquerades }\end{array}$ & corruption & stands & naked, & in its insolent impunity \\
\hline & Adjunct $^{1}$ & Subject & (Fused) Finite & Adjunct $^{2}$ & Adjunct $^{3}$ \\
\hline & Residue & Mood & & Residue & \\
\hline
\end{tabular}

\begin{tabular}{|c|c|c|c|c|}
\hline \multirow{8}{*}{ Clause 22 . } & \multicolumn{4}{|l|}{ Thematic analysis } \\
\hline & For sale to the highest bidder Interlocutory and perpetual injunctions & \multicolumn{3}{|c|}{ opulent criminals shop for pliant judges } \\
\hline & topical & & & \\
\hline & Theme (marked) & \multicolumn{3}{|l|}{ Rheme } \\
\hline & \multicolumn{4}{|l|}{ Mood analysis } \\
\hline & For sale to the highest bidder Interlocutory and perpetual injunctions & opulent criminals & shop for & pliant judges \\
\hline & Adjunct & Subject & (Fused) Finite & Complement \\
\hline & Residue & Mood & & Residue \\
\hline
\end{tabular}

\begin{tabular}{|l|l|l|l|}
\hline \multirow{4}{*}{ Clause 23. } & \multicolumn{2}{|l|}{ Thematic analysis } \\
\cline { 2 - 4 } & protect & the criminal \\
\cline { 2 - 4 } & topical & \\
\cline { 2 - 4 } & Theme & Rheme \\
\cline { 2 - 4 } & Mood analysis & protect & the criminal \\
\cline { 2 - 4 } & (Pliant judges) & (Fused) Finite & Complement \\
\cline { 2 - 4 } & (Elliptical Subject) & Residue \\
\cline { 2 - 3 } & Mood & \\
\hline
\end{tabular}




\begin{tabular}{|l|l|l|l|}
\hline \multirow{5}{*}{ Clause 24. } & \multicolumn{2}{|l|}{ Thematic analysis } \\
\cline { 2 - 3 } & enshrine & \multicolumn{2}{|l|}{ the crime } \\
\cline { 2 - 3 } & topical & \multicolumn{2}{|l}{} \\
\cline { 2 - 3 } & Theme & Rheme & the crime \\
\cline { 2 - 3 } & Mood analysis & enshrine & Complement \\
\cline { 2 - 3 } & (Pliant judges) & (Fused) Finite & Residue \\
\cline { 2 - 3 } & (elliptical Subject) & \\
\cline { 2 - 3 } & Mood & \\
\hline
\end{tabular}

\begin{tabular}{|c|c|c|c|c|c|}
\hline \multirow{7}{*}{ Clause 25.} & \multicolumn{5}{|c|}{ Thematic analysis } \\
\hline & And & Election Petition Tribunals & \multicolumn{3}{|c|}{ ah, bless those goldmines and bottomless booties! } \\
\hline & textual & topical & \multirow{2}{*}{\multicolumn{3}{|c|}{ Rheme }} \\
\hline & \multicolumn{2}{|l|}{ Theme } & & & \\
\hline & \multicolumn{5}{|c|}{ Mood analysis } \\
\hline & And & $\begin{array}{l}\text { Election Petition Tribunals, } \\
\text { ah }\end{array}$ & (God) & bless & those goldmines and bottomless booties! \\
\hline & & Complement $^{1}$ & Subject & (fused) Finite & Complement $^{2}$ \\
\hline
\end{tabular}

\begin{tabular}{|l|l|l|l|}
\hline \multirow{4}{*}{ Clause 26. } & \multicolumn{2}{|l|}{ Thematic analysis } & \multicolumn{2}{|l|}{ romp to electoral victory } \\
\cline { 2 - 4 } & Scoundrel vote-riggers & \\
\cline { 2 - 4 } & topical & \multicolumn{2}{|l|}{ Rheme } \\
\cline { 2 - 4 } & Theme & romp & to electoral victory \\
\cline { 2 - 4 } & Mood analysis & (Fused) Finite & Adjunct \\
\cline { 2 - 4 } & Scoundrel vote-riggers & Residue \\
\cline { 2 - 3 } & Subject & & \multicolumn{2}{|l}{} \\
\cline { 2 - 3 } & Mood &
\end{tabular}

\begin{tabular}{|l|l|l|l|}
\hline \multirow{4}{*}{ Clause 27. } & \multicolumn{2}{|l|}{ Thematic analysis } \\
\cline { 2 - 4 } & All & \multicolumn{2}{|l|}{ hail our buyable Bench and conniving Bar } \\
\cline { 2 - 4 } & topical & & \\
\cline { 2 - 4 } & Theme & Rheme \\
\cline { 2 - 4 } & Mood analysis & hail & our buyable Bench and conniving Bar \\
\cline { 2 - 4 } & All & (Fused) Finite & Complement \\
\cline { 2 - 3 } & Subject & Residue \\
\cline { 2 - 3 } & \multicolumn{2}{|l|}{ Mood } & \\
\hline
\end{tabular}

\begin{tabular}{|c|c|c|c|c|c|c|}
\hline \multirow{8}{*}{ Clause 28.} & \multicolumn{6}{|l|}{ Thematic analysis } \\
\hline & $\begin{array}{l}\text { A million dollars in Their Lordship's } \\
\text { bedroom, a million euros in the parlor closet, } \\
\text { countless naira beneath the kitchen sink }\end{array}$ & \multicolumn{5}{|c|}{ our courts are fast running out of Ghana-must-go's } \\
\hline & topical & & & & & \\
\hline & Theme & \multicolumn{5}{|l|}{ Rheme } \\
\hline & \multicolumn{6}{|l|}{ Mood analysis } \\
\hline & $\begin{array}{l}\text { A million dollars in Their Lordship's } \\
\text { bedroom, a million euros in the parlor closet, } \\
\text { countless naira beneath the kitchen sink }\end{array}$ & our courts & are & fast & running & $\begin{array}{l}\text { out of } \\
\text { Ghana-must-go's }\end{array}$ \\
\hline & Adjunct $^{1}$ & Subject & Finite & Adjunct $^{2}$ & Predicator & Adjunct $^{3}$ \\
\hline & Residue & \multicolumn{2}{|l|}{ Mood } & \multicolumn{3}{|l|}{ Residue } \\
\hline
\end{tabular}

\begin{tabular}{|c|c|c|c|c|}
\hline \multirow{8}{*}{ Clause 29.} & \multicolumn{4}{|l|}{ Thematic analysis } \\
\hline & The "Temple of Justice" & \multicolumn{3}{|c|}{ is broken in every brick } \\
\hline & topical & & & \\
\hline & Theme & \multicolumn{3}{|c|}{ Rheme } \\
\hline & \multicolumn{4}{|l|}{ Mood analysis } \\
\hline & The "Temple of Justice" & is & broken & in every brick \\
\hline & Subject & Finite & Predicator & Adjunct \\
\hline & \multicolumn{2}{|l|}{ Mood } & \multicolumn{2}{|l|}{ Residue } \\
\hline
\end{tabular}




\begin{tabular}{|c|c|c|c|c|c|}
\hline \multirow{5}{*}{ Clause 30.} & \multicolumn{5}{|c|}{ Thematic analysis } \\
\hline & The roof & \multicolumn{4}{|c|}{ is roundly perforated by termites of graft } \\
\hline & topical & & & & \\
\hline & \multicolumn{5}{|c|}{ Mood analysis } \\
\hline & The roof & is & roundly & perforated & by termites of graft \\
\hline
\end{tabular}

\begin{tabular}{|c|c|c|c|c|}
\hline \multirow{8}{*}{ Clause 31.} & \multicolumn{4}{|c|}{ Thematic analysis } \\
\hline & My Lord & \multicolumn{3}{|c|}{ tell me where to keep your bribe } \\
\hline & topical & & & \\
\hline & Theme & \multicolumn{3}{|l|}{ Rheme } \\
\hline & \multicolumn{4}{|c|}{ Mood analysis } \\
\hline & My Lord & tell & me & where to keep your bribe \\
\hline & Subject & (Fused) Finite & Complement & Adjunct \\
\hline & \multicolumn{2}{|c|}{ Mood (with won't you as Mood tag) } & \multicolumn{2}{|l|}{ Residue } \\
\hline
\end{tabular}

\begin{tabular}{|c|c|c|c|c|}
\hline \multirow{8}{*}{ Clause 32.} & \multicolumn{4}{|c|}{ Thematic analysis } \\
\hline & Judges & \multicolumn{3}{|c|}{ doze in the courtroom having spent all night, counting money and various "gifts" } \\
\hline & topical & \\
\hline & Theme & \multicolumn{3}{|l|}{ Rheme } \\
\hline & \multicolumn{4}{|c|}{ Mood analysis } \\
\hline & Judges & doze & $\begin{array}{l}\text { in the } \\
\text { courtroom }\end{array}$ & $\begin{array}{l}\text { having spent all night, counting money and various } \\
\text { "gifts" }\end{array}$ \\
\hline & Subject & (Fused) Finite & Adjunct $^{1}$ & Adjunct $^{2}$ \\
\hline & \multicolumn{2}{|l|}{ Mood } & \multicolumn{2}{|l|}{ Residue } \\
\hline
\end{tabular}

\begin{tabular}{|c|c|c|c|c|c|}
\hline \multirow{8}{*}{ Clause 33.} & \multicolumn{5}{|c|}{ Thematic analysis } \\
\hline & And & the Chief Justice & \multicolumn{3}{|c|}{ looks on with tired eyes as Corruption usurps his gavel } \\
\hline & textual & topical & & & \\
\hline & \multicolumn{2}{|l|}{ Theme } & \multicolumn{3}{|l|}{ Rheme } \\
\hline & \multicolumn{5}{|c|}{ Mood analysis } \\
\hline & And & the Chief Justice & looks on & with tired eyes & as Corruption usurps his gavel \\
\hline & & Subject & (Fused) Finite & Adjunct $^{1}$ & Adjunct $^{2}$ \\
\hline & & \multicolumn{2}{|l|}{ Mood } & \multicolumn{2}{|l|}{ Residue } \\
\hline
\end{tabular}

\begin{tabular}{|c|c|c|c|}
\hline \multirow{8}{*}{ Clause 34.} & \multicolumn{3}{|c|}{ Thematic analysis } \\
\hline & Crime & \multicolumn{2}{|c|}{ pays in this country } \\
\hline & topical & & \\
\hline & Theme & \multicolumn{2}{|l|}{ Rheme } \\
\hline & \multicolumn{3}{|c|}{ Mood analysis } \\
\hline & Crime & pays & in this country \\
\hline & Subject & (Fused) Finite & Adjunct \\
\hline & \multicolumn{2}{|l|}{ Mood } & Residue \\
\hline
\end{tabular}

\begin{tabular}{|l|l|l|l|}
\hline \multirow{4}{*}{ Thematic analysis } & \multicolumn{2}{|l|}{} \\
\cline { 2 - 4 } & Corruption & \multicolumn{2}{|l|}{ has its handsome rewards } \\
\cline { 2 - 4 } & topical & \multicolumn{2}{|l|}{} \\
\cline { 2 - 4 } & Theme & \multicolumn{2}{|l|}{ Rheme } \\
\cline { 2 - 4 } & Mood analysis & has & its handsome rewards \\
\cline { 2 - 4 } & Corruption & Finite & Complement \\
\hline & Subject & Residue \\
\cline { 2 - 3 } & \multicolumn{2}{|l}{} & \\
\hline
\end{tabular}




\begin{tabular}{|c|c|c|c|c|c|}
\hline \multirow{8}{*}{ Clause 36.} & \multicolumn{5}{|l|}{ Thematic analysis } \\
\hline & $\begin{array}{l}\text { Just one judgement sold to the richest } \\
\text { bidder }\end{array}$ & \multicolumn{4}{|c|}{ will catapult Judge \& Lawyer to the Billionaires' Club } \\
\hline & topical & & & & \\
\hline & Theme & \multicolumn{4}{|l|}{ Rheme } \\
\hline & \multicolumn{5}{|l|}{ Mood analysis } \\
\hline & $\begin{array}{l}\text { Just one judgement sold to the richest } \\
\text { bidder }\end{array}$ & will & catapault & Judge \& Lawyer & to the Billionaires' Club \\
\hline & Subject & Finite & Predicator & Complement & Adjunct \\
\hline & \multicolumn{2}{|l|}{ Mood } & \multicolumn{3}{|l|}{ Residue } \\
\hline
\end{tabular}

\begin{tabular}{|c|c|c|c|c|c|}
\hline \multirow{8}{*}{ Clause 37.} & \multicolumn{5}{|l|}{ Thematic analysis } \\
\hline & The Law, they say, & \multicolumn{4}{|c|}{ is an ass sometimes fast, sometimes slow } \\
\hline & topical & & & & \\
\hline & Theme & \multicolumn{4}{|l|}{ Rheme } \\
\hline & \multicolumn{5}{|l|}{ Mood analysis } \\
\hline & The Law, they say, & is & an ass & sometimes fast, & sometimes slow \\
\hline & Subject & Finite & Complement & Adjunct $^{1}$ & Adjunct $^{2}$ \\
\hline & \multicolumn{2}{|l|}{ Mood } & \multicolumn{3}{|l|}{ Residue } \\
\hline
\end{tabular}

\begin{tabular}{|c|c|c|c|c|}
\hline \multirow{8}{*}{ Clause 38.} & \multicolumn{4}{|c|}{ Thematic analysis } \\
\hline & But & The Law in Nigeria & \multicolumn{2}{|c|}{ is a vulture fat on the cash-and-carry carrion of murdered Conscience } \\
\hline & textual & topical & & \\
\hline & \multicolumn{2}{|l|}{ Theme } & \multicolumn{2}{|l|}{ Rheme } \\
\hline & \multicolumn{4}{|c|}{ Mood analysis } \\
\hline & But & the Law in Nigeria & is & a vulture fat on the cash-and-carry carrion of murdered Conscience \\
\hline & & Subject & Finite & Complement \\
\hline & & \multicolumn{2}{|l|}{ Mood } & Residue \\
\hline
\end{tabular}

\begin{tabular}{|c|c|c|c|c|}
\hline \multirow{8}{*}{ Clause 39.} & \multicolumn{4}{|c|}{ Thematic analysis } \\
\hline & They & \multicolumn{3}{|c|}{ kill our trust in the common good, these Monsters of Mammon in their garish gowns } \\
\hline & topical & & & \\
\hline & Theme & \multicolumn{3}{|l|}{ Rheme } \\
\hline & \multicolumn{4}{|c|}{ Mood analysis } \\
\hline & They & kill & our trust in the common good & these Monsters of Mammon in their garish gowns \\
\hline & Subject $^{1}$ & (Fused) Finite & Complement & Subject $^{2}$ (discontinuous Subject) \\
\hline & \multicolumn{2}{|l|}{ Mood } & \multicolumn{2}{|l|}{ Residue } \\
\hline
\end{tabular}

\begin{tabular}{|c|c|c|c|c|c|c|}
\hline \multirow{8}{*}{ Clause 40.} & \multicolumn{6}{|c|}{ Thematic analysis } \\
\hline & Unhappy & \multicolumn{5}{|c|}{ the land where jobbers are judges, where impunity walks the streets, like a large, invincible Demon } \\
\hline & topical & & & & & \\
\hline & Theme & \multicolumn{5}{|l|}{ Rheme } \\
\hline & \multicolumn{6}{|l|}{ Mood analysis } \\
\hline & unhappy & (is) & the land & where jobbers are judges & $\begin{array}{l}\text { where impunity walks } \\
\text { the streets }\end{array}$ & $\begin{array}{l}\text { like a large, } \\
\text { invincible Demon }\end{array}$ \\
\hline & Complement $^{1}$ & (elliptical Finite & Subject & Adjunct $^{1}$ & Adjunct $^{2}$ & Adjunct $^{3}$ \\
\hline & Residue & \multicolumn{2}{|l|}{ Mood Block } & \multicolumn{3}{|l|}{ Residue } \\
\hline
\end{tabular}

\begin{tabular}{|c|c|c|c|c|}
\hline \multirow{8}{*}{ Clause 41.} & \multicolumn{4}{|c|}{ Thematic analysis } \\
\hline & Come Sunday & \multicolumn{3}{|c|}{ They troop to the church } \\
\hline & topical & & & \\
\hline & Theme & \multicolumn{3}{|l|}{ Rheme } \\
\hline & \multicolumn{4}{|l|}{ Mood analysis } \\
\hline & Come Sunday & they & troop & to the church \\
\hline & Adjunct $^{1}$ & Subject & (Fused) Finite & Adjunct $^{2}$ \\
\hline & Residue & \multicolumn{2}{|c|}{ Mood Block } & Residue \\
\hline
\end{tabular}




\begin{tabular}{|c|c|c|c|c|c|}
\hline \multirow{8}{*}{ Clause 42.} & \multicolumn{5}{|c|}{ Thematic analysis } \\
\hline & Friday & \multicolumn{4}{|c|}{ they mouth their manthra in pious mosques } \\
\hline & topical & & & & \\
\hline & Theme & \multicolumn{4}{|l|}{ Rheme } \\
\hline & \multicolumn{5}{|c|}{ Mood analysis } \\
\hline & Friday & they & mouth & their mantra & in pious mosques \\
\hline & Adjunct $^{1}$ & Subject & (Fused) Finite & Complement & Adjunct $^{2}$ \\
\hline & Residue & \multicolumn{2}{|l|}{ Mood } & \multicolumn{2}{|l|}{ Residue } \\
\hline
\end{tabular}

\begin{tabular}{|l|l|l|l|l|l|}
\hline \multirow{4}{*}{} & \multicolumn{4}{|l|}{ Theme-Rheme structure } \\
\cline { 2 - 5 } & But & they & \multicolumn{2}{l|}{ pervert justice all week long } \\
\hline \multirow{4}{*}{ Clause 43. } & toptual & \multicolumn{2}{l|}{} \\
\cline { 2 - 5 } & Theme & Rheme & all week long \\
\cline { 2 - 5 } & Modal structure & pervert & justice & Adjunct \\
\cline { 2 - 5 } & But & they & (Fused) Finite & Complement \\
\cline { 2 - 5 } & (Conjunct) & Subject & Residue & \\
\cline { 2 - 4 } & Mood &
\end{tabular}

\begin{tabular}{|c|c|c|c|c|c|c|}
\hline \multirow{8}{*}{ Clause 44.} & \multicolumn{6}{|c|}{ Thematic analysis } \\
\hline & And & dig & \multicolumn{4}{|c|}{ us deeper into the hellish hole } \\
\hline & textual & topical & & & & \\
\hline & \multicolumn{2}{|l|}{ Theme } & \multicolumn{4}{|l|}{ Rheme } \\
\hline & \multicolumn{6}{|c|}{ Mood analysis } \\
\hline & And & (they) & dig & us & deeper & into the hellish hole \\
\hline & (Conjunct) & (elliptical Subject) & (Fused) Finite & Complement & Adjunct $^{1}$ & Adjunct $^{2}$ \\
\hline & & \multicolumn{2}{|l|}{ Mood } & \multicolumn{3}{|l|}{ Residue } \\
\hline
\end{tabular}

\begin{tabular}{|c|c|c|c|}
\hline \multirow{8}{*}{ Clause 45.} & \multicolumn{3}{|c|}{ Thematic analysis } \\
\hline & Nigeria & \multicolumn{2}{|c|}{ is a huge corpse With milling maggots on its wretched hulk } \\
\hline & topical & & \\
\hline & Theme & \multicolumn{2}{|l|}{ Rheme } \\
\hline & \multicolumn{3}{|c|}{ Mood analysis } \\
\hline & Nigeria & is & a huge corpse With milling maggots on its wretched hulk \\
\hline & Subject & Finite & Complement \\
\hline & \multicolumn{2}{|l|}{ Mood } & Residue \\
\hline
\end{tabular}

\begin{tabular}{|c|c|c|c|}
\hline \multirow{8}{*}{ Clause 46.} & \multicolumn{3}{|c|}{ Thematic analysis } \\
\hline & They & \multicolumn{2}{|l|}{ prey every day } \\
\hline & topical & & \\
\hline & Theme & \multicolumn{2}{|l|}{ Rheme } \\
\hline & \multicolumn{3}{|c|}{ Mood analysis } \\
\hline & They & prey & every day \\
\hline & Subject & (Fused) Finite & Adjunct \\
\hline & \multicolumn{2}{|l|}{ Mood } & Residue \\
\hline
\end{tabular}

\begin{tabular}{|c|c|c|c|c|}
\hline \multirow{8}{*}{ Clause 47.} & \multicolumn{4}{|c|}{ Thematic analysis } \\
\hline & They & \multicolumn{3}{|l|}{ prey every night } \\
\hline & topical & & & \\
\hline & Theme & \multicolumn{3}{|l|}{ Rheme } \\
\hline & \multicolumn{4}{|c|}{ Mood analysis } \\
\hline & They & prey & every night & for the endless decomposition of our common soul \\
\hline & Subject & (Fused) Finite & Adjunct $^{1}$ & Adjunct $^{2}$ \\
\hline & \multicolumn{2}{|l|}{ Mood } & \multicolumn{2}{|l|}{ Residue } \\
\hline
\end{tabular}




\begin{tabular}{|c|c|c|c|c|c|}
\hline \multirow{8}{*}{ Clause 48 . } & \multicolumn{5}{|l|}{ Thematic analysis } \\
\hline & My most honourable Lord & \multicolumn{4}{|c|}{ just tell me where to keep your bribe } \\
\hline & topical & & & & \\
\hline & Theme & \multicolumn{4}{|l|}{ Rheme } \\
\hline & \multicolumn{5}{|l|}{ Mood analysis } \\
\hline & My most honourable Lord & just & tell & me & where to keep your bribe \\
\hline & Subject & Adjunct $^{1}$ & (Fused) Finite & Complement & Adjunct $^{2}$ \\
\hline & Mood & Residue & Mood & Residue & \\
\hline
\end{tabular}

\section{Copyrights}

Copyright for this article is retained by the author(s), with first publication rights granted to the journal.

This is an open-access article distributed under the terms and conditions of the Creative Commons Attribution license (http://creativecommons.org/licenses/by/4.0/). 